\title{
Pelatihan dan Pendampingan Sertifikasi Profesi Teknisi Akuntansi bagi Guru SMK Akuntansi se-Kabupaten Tulungagung untuk Menghadapi Persaingan Era Masyarakat Ekonomi Asean (MEA)
}

\author{
Slamet Fauzan*1, Dhika Maha Putri², Agfia Fauziatul Ulfa ${ }^{3}$ \\ 1,2Program Studi Pendidikan Akuntansi, Universitas Negeri Malang, Indonesia \\ ${ }^{3}$ Akuntansi, Fakultas Ekonomi, Universitas Negeri Malang, Indonesia \\ *e-mail: slamet.fauzan.fe@um.ac.id'1 ${ }^{1}$, dhika.maha.fe@um.ac.id², \\ agfia.fauziatul.1804216@students.um.ac.id ${ }^{3}$
}

\begin{abstract}
Abstrak
Pentingnya pengakuan atas kompetensi yang dimiliki oleh seorang guru mendorong diadakannya pelatihan dan pendampingan terkait kurangnya pemahaman sertifikasi profesi teknisi akuntansi bagi guru SMK se-Kabupaten Tulungagung. Salah satu upaya peningkatan kualifikasi pendidikan di Indonesia dimanifestasikan melalui peranan profesi guru. Tolak ukur kompetensi profesional guru dalam proses pembelajaran ditandai dengan kepemilikan sertifikat profesi. Bentuk sertifikasi profesi ataupun uji kompetensi guru juga menjadi salah satu program yang diselenggarakan oleh pemerintah di Indonesia. Tujuan dari pengabdian ini agar guru SMK Jurusan Akuntansi Kabupaten Tulungagung memahami dan menyiapkan sertifikasi uji kompetensi. Metode yang digunakan yaitu pelatihan dan pendampingan dalam penyusunan laporan keuangan yang sesuai dengan uji kompetensi. Hasil yang didapatkan pada kegiatan ini adalah para guru SMK se-Kabupaten Tulungagung memahami apa saja yang harus disiapkan dalam serifikasi profesi akuntansi bagi guru. Hal ini terlihat dari hasil wawancara kepada peserta pelatihan bahwa 80\% persen peserta meningkat pemahamannya terkait uji kompetensi akuntansi. Dimana tingkat pemahaman peserta sebelum pelatihan hanya 50\% terkait uji kompetensi.
\end{abstract}

Kata kunci: Kualitas Pendidikan, Profesi Guru, Sertifikasi Profesi

\begin{abstract}
The importance of recognizing the competence possessed by a teacher encourages the holding of training and assistance related to the lack of understanding of accounting technician professional certification for vocational school teachers throughout Tulungagung Regency. One of the efforts to improve educational qualifications in Indonesia is manifested through the role of the teaching profession. The benchmark of teacher professional competence in the learning process is marked by the possession of a professional certificate. The form of professional certification or teacher competency testing is also one of the programs organized by the government in Indonesia. The purpose of this service is for teachers of SMK Accounting Department in Tulungagung Regency to understand and prepare competency test certification. The method used is training and assistance in the preparation of financial reports in accordance with the competency test. The results obtained in this activity are vocational teachers throughout Tulungagung Regency understand what must be prepared in the certification of the accounting profession for teachers. This can be seen from the results of interviews with training participants that $80 \%$ percent of participants increased their understanding of accounting competency tests. Where the level of understanding of the participants before the training was only $50 \%$ related to the competency test.
\end{abstract}

Keywords: Professional Certification, Quality of Education, Teaching Profession

\section{PENDAHULUAN}

Indonesia merupakan bagian dari perkembangan dari Asean Economic Community yang sekaligus menjadi tantangan terberat yang akan dihadapi. Sumber daya manusia di Indonesia masih menjadi tugas terberat bangsa dalam meningkatkan kualitas dan daya bersaing dengan negara di Asia Tenggara (Ansori et al., 2017). Pasalnya Indonesia sangat tertinggal dibandingan negara lain yaitu berada di peringkat 50 dari 141 negara. Hasil survei dari UNESCO Indonesia menempati posisi 14 dari 14 negara berkembang karena kurangnya kualifikasi Pendidikan di Indonesia. Aspek Pendidikan merupakan salah satu solusi untuk memperbaiki peringkat 
Indonesia menjadi lebih baik dan menciptakan sumber daya manusia yang berkualitas dan mampu bersaing. Pendidikan di Indonesia merupakan satu dari banyaknya aspek terpenting dalam proses pertumbuhan di Indonesia. Pendidikan merupakan faktor terpenting dalam membentuk karakter dan kepribadian anak bangsa. Pemerintah sebagai penyelenggara dalam keberlangsungan Pendidikan di Indonesia sangat berhati-hati dalam menangai proses Pendidikan di Indonesia. Keberhasilan Pendidikan dilihat dari lahirnya generasi bangsa yang berkualitas dan mampu bersaing (Nurbaiti, 2019). Profesi guru merupakan salah satu dari keberhasilan dari proses Pendidikan di Indonesia. Berdasarkan Undang-Undang Republik Indonesia Nomor 14 Tahun 2005 Tentang Guru Dan Dosen menjelaskan bahwa guru adalah pendidik profesional dengan tugas utama mendidik, mengajar, membimbing, mengarahkan, melatih, menilai, dan mengevaluasi peserta didik pada pendidikan anak usia dini jalur pendidikan formal, pendidikan dasar, dan pendidikan menengah.

Guru merupakan salah satu peran yang menjadi ujung tombak dalam keberhasilan Pendidikan di Indonesia (Muslimin, 2020). Terselenggaranya proses Pendidikan di Indonesia tidak pernah lupa dengan campur tangan seorang guru yang berperan sebagai tenaga pendidik (Wardhani, 2017). Upaya memperbaiki Pendidikan di Indonesia salah satunya yaitu dengan menetapkan kebijakan bahwa setiap guru yang profesional harus memiliki sertifikasi uji kompetensi. Sertifikat profesi guru menjadi tolak ukur bahwa seorang guru telah memenuhi kualifikasi dalam akademiknya dan mendapat pengakuan sebagai guru profesional oleh masyarakat Indonesia (Ansori et al., 2017). Di Indonesia menjadi seorang guru harus memiliki kualifikasi sebagai lulusan sarjana atau setara dengan diploma empat. Sebagaimana telah ditetapkan dalam Undang-Undang RI Nomor 14 Tahun 2005 Tentang Guru Dan Dosen bahwa seorang guru harus memiliki kualifikasi akademik, kompetensi, sertifikat pendidik, sehat jasmani dan rohani, serta memiliki kemampuan untuk mewujudkan tujuan pendidikan nasional. Oleh sebab itu seorang guru harus dapat meningkatkan wawasan ilmu pengetahuannya sesuai kemajuan perkembangan zaman.

Uji kompetensi guru merupakan salah satu program yang diberikan pemerintah dalam meningkatkan kualitas Pendidikan di Indonesia. Uji Kompetensi Guru (UKG) atau sering disebut sertifikasi profesi (Wardhani, 2017) ini dapat mengukur sejauh mana kompetensi profesional guru dalam proses pendidikan. Guru Akuntansi merupakan guru produktif pada kejuruan akuntansi di SMK yang mengemban amanah untuk menyampaikan ilmu akuntansinya. Pentingnya kemampuan guru akuntansi dalam mengulas kompetensi kejuruan akuntansi yang sesuai dengan SKKNI (Standar Kompetensi Kerja Nasional Indonesia) diperjelas oleh (Kardiyem, 2013) bahwa mata pelajaran akuntansi memiliki tujuan untuk dapat memenuhi standar akuntansi dalam dunia kerja.

Berdasarkan dari permasalahan dalam Pendidikan yang terjadi di Indonesia kini telah hadir Tim Pengabdian Kepada Masyarakat Fakultas Ekonomi Universitas Negeri Malang dengan memberikan solusi untuk meningkatkan professional guru dalam melahirkan lulus terbaik bangsa khususnya dalam bidang akuntansi. Kegiatan pengabdian kepada masyarakat ini ditujukan untuk guru SMK Akuntansi se-Kabupaten Tulungagung dengan tujuan memberikan pemahaman bahwa sertifikasi profesi teknisi akuntansi itu penting bagi setiap guru SMK Akuntansi se-Kabupaten Tulungagung dalam melahirkan peserta didik yang berkualitas dan memiliki daya saing tinggi. Selain itu tim pengabdian kepada masyarakat memberikan pendampingan pelatihan uji sertifikasi profesi teknisi akuntansi kepada guru SMK Akuntansi se-Kabupaten Tulungagung.

Untuk meningkatkan pemahaman guru akuntasi di MGMP Tulungagung maka perlu pelatihan dan pendampingan penyusunan laporan keuangan sesuai dengan uji kompetensi. Pelatihan ini terkait apa saja yang harus disiapkan dalam uji kompetensi serta bagaiamana tips dan triknya agar kompeten dalam uji kompetensi.

\section{METODE}

Metode yang di gunakan dalam kegiatan pelatihan dan pendampingan sertifikasi profesi teknisi akuntansi bagi guru SMK akuntansi se-Kabupaten Tulungagung menggunakan analisis 
kualitatif dan menggunakan metode andragogi. Metode andragogi merupakan metode dengan memusatkan pada partisipan melalui sosialisasi/pendampingan, diskusi bersama, dan tanyajawab (Hasibuan et al., 2021). Alur pelaksanaan kegiatan pelatihan dan pendampingan sertifikasi profesi akuntansi di kabupaten Tulungagung sebagai berikut:

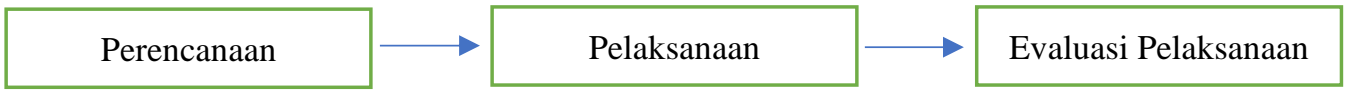

Gambar 1. Alur Pelaksanaan Kegiatan

\subsection{Perencanaan}

Pada tahap perencanaan yang dilakukan oleh Tim Pengabdian yaitu mempersiapkan keperluan apa saja yang akan dibutuhkan. Pada tahap perencanaan terdiri dari:

1. Melakukan koordinasi dengan ketua MGMP Akuntansi di Kabupaten Tulungagung

2. Mempersiapkan materi pelatihan sertifikasi profesi akuntansi

3. Menyusun jadwal untuk pelaksanaan pelatihan dan pendampingan sertifikasi profesi teknisi akuntansi bagi guru SMK akuntansi se-Kabupaten Tulungagung

\subsection{Pelaksanaan}

Pada tahap pelaksanaan yang dilakukan oleh tim pengabdian yaitu memberikan kegiatan pelatihan dan pendampingan kepada guru SMK Akuntansi di Kabupaten Tulungagung. Kegiatan pertama merupakan pelatihan/sosialisasi kepada guru SMK Akuntansi di Kabupaten Tulungagung dengan menghadirkan pemateri dalam bidang akuntansi yaitu dosen Akuntansi Universitas Negeri Malang. Kegiatan kedua merupakan pendampingan kepada guru SMK Akuntansi di Kabupaten Tulungagung dengan melakukan diskusi bersama, tanyajawab dan praktik secara langsung dengan guru SMK Akuntansi di Kabupaten Tulungagung. Pendampingan ini dilakukan untuk mengetahui keberhasilan dari pelatihan yang telah disampaikan oleh pemateri. Selain itu pada pendampingan ini tim pengabdian dapat mengetahui hambatan hambatan apa saja yang dialami oleh guru SMK Akuntansi di Kabupaten Tulungagung sebelum menghadapi ujian sertifikasi profesi teknisi akuntansi.

\subsection{Evaluasi Pelaksanaan}

Pada tahap evaluasi pelaksanaan yang dilakukan oleh tim pengabdian yaitu melakukan survei mengenai tingkat pemahaman dan tingkat pengetahuan terhadap sertifikasi profesi teknisi akuntansi. Selain itu tim pengabdian melakukan monitoring setelah pelatihan dan pendampingan selesai. Pada tahap monitoring tim pengabdian memberikan alternatif solusi, tips dan trik yang dapat diterapkan secara langsung oleh guru SMK Akuntansi di Kabupaten Tulungagung pada saat ujian sertifikasi berlangsung.

\section{HASIL DAN PEMBAHASAN}

Sertifikasi profesi teknisi akuntansi bagi guru SMK Akuntansi merupakan profesi penting bagi guru untuk dapat mengetahui kemampuan dan kewenangan yang dimiliki oleh guru akuntansi dalam unit kerjanya, yang dilandaskan pada pengetahuan, pemahaman, keterampilan, dan sikap sebagai guru akuntansi. Oleh karena itu tim pengabdian kepada masyarakat Fakultas Ekonomi Universitas Negeri Malang memberikan pelatihan dan pendampingan kepada guru SMK Akuntansi se-Kabupaten Tulungagung. Kegiatan pelatihan dan pendampingan berlangsung selama kurang lebih 7 hari dimulai dari persiapan oleh tim pengabdian kepada masyarakat hingga pelaporan kegiatan. Pelaksanaan kegiatan pelatihan dan pendampingan sertifikasi profesi teknisi akuntansi yang bertempat di SMK PGRI 1 Tulungagung dilaksanakan pada hari Senin, 28 Juni 2021.

Kegiatan pelatihan dan pendampingan dilakukan untuk melihat tingkat pemahaman dan tingkat pengatahuan bahwa pentingnya sertifikasi profesi teknisi akuntansi oleh guru SMK 
Akuntansi di Kabupaten Tulungagung. Rangkaian acara pada kegiatan pelatihan dan pendampingan sertifikasi profesi teknisi akuntansi sebagai berikut:

1. Sambutan dari Bapak Dr. Cipto Wardoyo, S.E., M.Pd., M.Si., Ak., CA sebagai Dekan Fakultas Ekonomi Universitas Negeri Malang.

2. Sambutan dari kepala sekolah SMK PGRI 1 Tulungagung.

3. Sambutan dari Bapak Rohadiyono, S.Pd. sebagai ketua MGMP Kabupaten Tulungagung.

4. Penyampaian materi pertama oleh Bapak Rizky Firmansyah, S.E., M.S.A. sebagai dosen Akuntansi di Universitas Negeri Malang.

5. Penyampaian materi kedua oleh Bapak Slamet Fauzan, S.Pd., M.Pd. sebagai dosen Akuntansi di Universitas Negeri Malang.

6. Pendampingan pelatihan sertifikasi profesi akuntansi oleh Tim Pengabdian Kepada Masyarakat.

7. Penutupan.

Penyampaian materi dalam kegiatan pelatihan dan pendampingan sertifikasi profesi teknisi akuntansi terdiri dari dua materi. Pemateri yang pertama menyampaikan gambaran umum mengenai pentingnya sertifikasi profesi akuntansi bagi guru SMK Akuntansi khususnya di Kabupaten Tulungagung. Pemateri yang kedua menyampaikan materi pelatihan skema uji sertifikasi profesi teknisi akuntansi level 1 . Selain itu kedua pemateri memberikan cara yang efektif dalam mengerjakan soal - soal ujian sertifikasi profesi teknisi akuntansi kepada guru SMK Akuntansi di Kabupaten Tulungagung.

Berikut list materi pengabdian pelatihan sertifikasi kompetensi akuntansi yang diberikan kepada peserta:

1. Pentingnya sertifikasi.

2. Menyusun jurnal.

3. Menyusun buku besar.

4. Menyusun laporan keuangan.

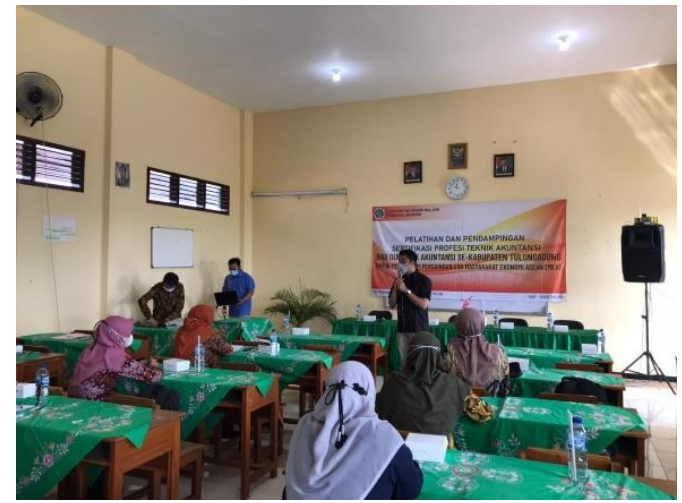

Gambar 1. Penyampaian Materi oleh Narasumber pertama

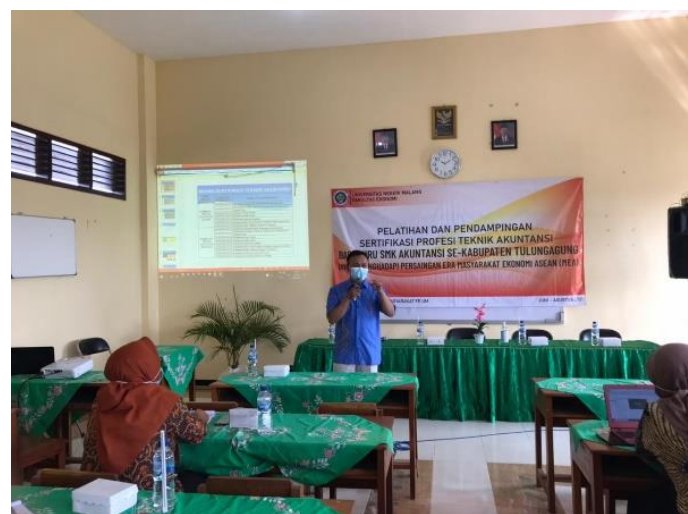

Gambar 2. Penyampaian Materi oleh Narasumber kedua 
Kegiatan yang terakhir merupakan pendampingan pelatihan ujian sertifikasi profesi teknisi akuntansi oleh Tim Pengabdian Kepada Masyarakat kepada guru SMK Akuntansi di Kabupaten Tulungagung. Pendampingan ini dilakukan oleh semua Tim Pengabdian Kepada Masyarakat yang terjun langsung menghampiri guru SMK Akuntansi yang sebelumnya telah mengikuti sosialisasi yang disampaikan oleh dua pemateri dari dosen Akuntansi Universitas Negeri Malang. Pada sesi ini berlangsungnya interaksi/diskusi antara tim pengabdian kepada masyarakat dan peserta mengenai praktik ujian sertifikasi profesi teknisi akuntansi. Tim PKM memberikan pendambingan mengenai pengerjaan uji sertifikasi profesi teknisi akuntansi kepada guru SMK Akuntansi secara bergantian dan terstruktur. Proses diskusi dan tanya jawab dilakukan selama 2 jam 30 menit dengan tujuan untuk peserta dapat menyampaikan kekurangan dan kesulitan yang dialami selama praktik simulasi uji sertifikasi profesi teknisi akuntansi.

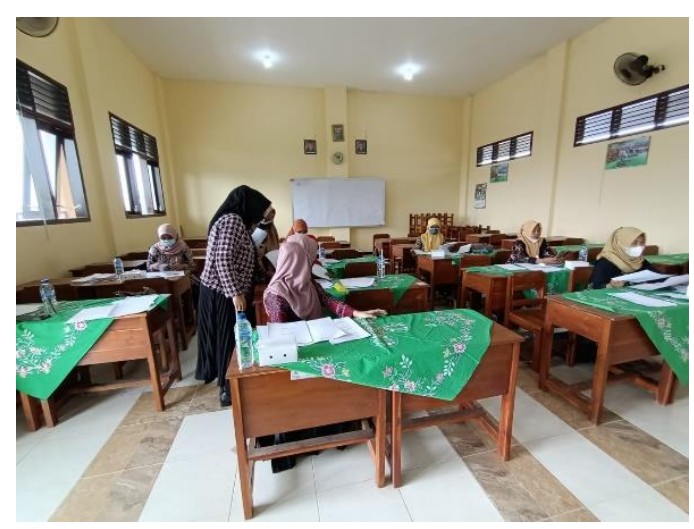

Gambar 3. Pendampingan Pelatihan Uji Sertifikasi Profesi Teknisi Akuntansi

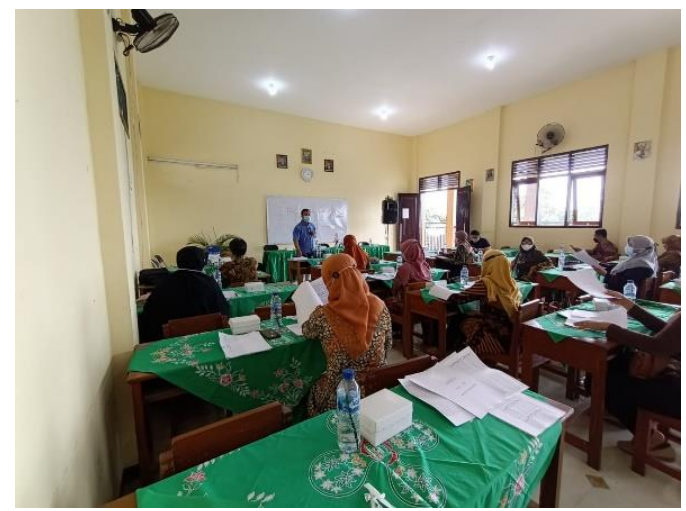

Gambar 4. Pendampingan Pelatihan Uji Sertifikasi Profesi Teknisi Akuntansi

Kegiatan pelatihan dan pendampingan sertifikasi profesi teknisi akuntansi memfokuskan pada unit siklus akuntansi yaitu penyusunan laporan keuangan. Berikut merupakan elemen dalam uji kompetensi sertifikasi profesi teknisi akuntansi dan kriteria yang ditetapkan dalam proses penyusunan laporan keuangan.

Kegiatan pelatihan dan pendampingan uji kompetensi akuntansi memiliki manfaat yang besar bagi para guru SMK Akuntansi se-Kabupaten Tulungagung. Manfaat yang diperoleh adalah peserta dapat memahami bagaimana cara menyelesaikan soal-soal dalam uji kompetensi sertifikasi profesi akuntansi, memahami pentingnya sertifikasi kompetensi bagi guru dan lulusan, dan terjalinnya kerjasama antara pihak universitas sebagai penyedia tenaga kerja yang kompeten dengan guru SMK Akuntansi se-Kabupate Tulungagung. Hal ini terlihat dari hasil wawancara kepada peserta pelatihan bahwa $80 \%$ persen peserta meningkat pemahamannya terkait uji kompetensi akuntansi. Dimana tingkat pemahaman peserta sebelum pelatihan hanya $50 \%$ terkait uji kompetensi. 


\section{KESIMPULAN}

Berdasarkan pembahasan diatas bahwa pelaksanaan kegiatan pengabdian kepada masyarakat yang dilakukan oleh Tim Pengabdian Kepada Masyarakat Universitas Negeri Malang telah terlaksana dengan baik. Hal tersebut dapat dilihat dari antusiasme dari para guru SMK Akuntansi se-Kabupaten Tulungagung yang menyambut tim pengabdian dengan respon yang baik dan dengan semangat tinggi. Antusiasme peserta terlihat selama proses kegiatan berlangsung yaitu menyimak penjelasan yang disampaikan pemateri mengenai pentingnya sertifikasi profesi teknisi akuntansi bagi guru dan lulusan peserta didik jurusan akuntansi. Selain itu dalam proses pendampingan latihan uji kompetensi teknisi akuntansi peserta aktif dalam diskusi dan tanya jawab kepada tim pengabdian. Hal ini terlihat dari hasil wawancara peserta selama pelatihan bahwa $80 \%$ peserta meningkat pemahamannya terkait uji kompetensi akuntansi. Dimana tingkat pemahaman peserta sebelum pelatihan hanya 50\% terkait uji sertifikasi kompetensi.

\section{UCAPAN TERIMA KASIH}

Tim pengabdian kepada masyarakat mengucapkan terimakasih kepada pihak Fakultas Ekonomi Univeritas Negeri Malang yang telah memberikan dukungan sepenuhnya dalam proses pelatihan dan pendampingan kepada guru SMK Akuntansi di Kabupaten Tulungagung. Selain itu tidak lupa kami tim pengabdian kepada masyarakat mengucapkan terimakasih kepada ketua MGMP Kabupaten Tulungagung dan guru SMK Akuntansi se-Kabupaten Tulungagung yang telah senantiasa mengikuti semua rangkaian acara dalam kegiatan pelatihan dan pendampingan sertifikasi profesi teknisi akuntansi bagi guru SMK Akuntansi di Kabupaten Tulungagung.

\section{DAFTAR PUSTAKA}

Ansori, M., Arief, S., \& Sukirno. (2017). Profesionalisme Guru Akuntansi Pasca Sertifikasi. Jurnal $\begin{array}{lllll}\text { Pendidikan Ekonomi Dan Bisnis (JPEB), } & 7(1), & 107-126 .\end{array}$ https://doi.org/http://doi.org/10.21009/JPEB

Hasibuan, D. K., Indriyani, N., \& Limbong, C. H. (2021). Pelatihan Akuntansi PSAK dan Penyusunan Laporan Keuangan Bagi Masyarakat Desa. Jurnal Pengabdian Kepada Masyarakat, 1(1), 7-12. https://doi.org/10.31849/dinamisia.v3i1.2729

Kardiyem. (2013). ANALISIS KINERJA GURU PASCASERTIFIKASI (Studi Empiris pada Guru Akuntansi SMK Se-Kabupaten Grobogan). The Journal of Economic Education, 2(1), 18-23. http://journal.unnes.ac.id/sju/index.php/jeec

Muslimin, M. (2020). Program Penilaian Kinerja Guru dan Uji Kompetensi Guru dalam Meningkatkan Prestasi Kerja Guru. Indonesian Journal of Education Management \& Administration Review, 4(1), https://jurnal.unigal.ac.id/index.php/ijemar/article/view/4384

Nurbaiti. (2019). Implementasi Kebijakan Uji Kompetensi Guru ( Ukg ) Dinas Pendidikan Pemuda Dan Olahraga Kota Palembang. Prosiding Seminar Nasional Pendidikan Program Pascasarjana Universitas Pgri Palembang, 650-663.

Undang-Undang RI Nomor 14 Tahun 2005 tentang Guru dan Dosen, 1 (2005).

Wardhani, F. R. (2017). Analisis Kompetensi Guru Berbasis Uji Kompetensi Guru (UKG) Pada Guru Sekolah Menengah Kejuruan (SMK) Bidang Keahlian Administrasi Perkantoran di Surakarta Tahun Ajaran 2015 / 2016. Jurnal Informasi Dan Komunikasi Administrasi Perkantoran, 1(1), 75-84. http://jurnal.fkip.uns.ac.id/index.php/jikap 